A N NALES

UNIVERSITATIS MARIAE CURIE-SKŁODOWSKA LUBLIN - POLONIA

VOL. XXXV

SECTIO FF

$1-2017$

KATARZYNA STADNIK

Maria Curie-Skłodowska University

\title{
Constructing the Temporal Granularity of Narrative Events in Zbigniew Herbert's Attempt at a Description of the Greek Landscape
}

Konstruowanie wymiaru temporalnego wydarzeń w narracji
na przykładzie Próby opisania krajobrazu greckiego Zbigniewa Herberta

\section{NARRATIVE THROUGH THE LENS OF COGNITIVE-CULTURAL LINGUISTICS}

Narratives can be theorised differently, depending on the researcher's academic background. One form of narrative medium is literature, and it is the form of a literary written narration that constitutes the focus of the present study. This choice has a number of vital implications for our analysis. Narratives are integral to various cultures due to "the culture's need to represent events and cultural norms in forms which guarantee their temporally extended availability" (Dancygier, 2012:28). As further clarified by Horton,

[...] successful communication is not simply a matter of encoding and decoding messages. Instead, language use is seen as being rooted in a set of powerful inferential mechanisms through which speakers and addressees consider contextually available information as an essential part of conveying and understanding meaning. As especially prominent type of contextual information is knowledge about one's interlocutor - and in particular the knowledge that interlocutors believe they have in common. This concept of shared knowledge, along with the related concepts of common ground and mutual knowledge, has had a tremendous impact upon theoretical accounts of language use and human communication (Horton, 2012:375).

Since we aim to explore the cognitive-cultural aspects of the human capacity to tell and comprehend stories using language, the central assumption pertains to the 
theoretical-methodological framework in which the research is conducted. Specifically, the cultural-cognitive profile of the study ought to be properly recognised. Cultural Linguistics, defined as the study of the relation between the human mind, language and culture, originating from the Cognitive Linguistic enterprise, constitutes the footing for the investigation (cf. Sharifian, 2016). Accounting for the cognitive component entails the need to tap into the framework of cognitive approaches to the analysis of a literary text. As Dancygier (2012:4-5) puts it,

[e]lucidating the emergence of meaning in various storytelling contexts [...] requires adopting a methodology which is sensitive enough to fine-grained linguistic details, while opening itself up to questions about cultural context, our cognitive capacities, and the simple fact of there being various ways to interpret any storytelling artifact.

The human cognitive ability to categorise underlies narrative expression. The capacity for categorisation helps us structure the flux of experience into malleable chunks instrumental in meaning construction. Consisting of conceptual components such as scenes, objects, people (cf. Tversky, Zacks and Hard, 2007), narrative can be viewed as an information-bearing, complex pattern, the structure of which derives from the nature of human cognitive abilities. Indeed, narratives constitute tools for thinking in that "the strategies [of chunking experience, imputing causal relations among events, framing events] allow one to construct events as bounded concepts appearing in a sequence and linked causally" (Dancygier, 2012:15). As for the fictitious status of some narrative events, Dancygier elucidates that

[linguistic] symbols are not detached from the real world; on the contrary, they are immersed in it via their reliance on image schemas and action. Categories and symbolic concepts are thus related to other categories and concepts not on the basis of the system of related meanings, but on the basis of underlying shared experiential concepts. [...] The fact that the events to be conceptualized are fictitious is not an obstacle to conceptualization. Naturally, narratives make heavy demands on cultural knowledge, memory, empathy, and other aspects of cognition, but they are not encumbered by the need to refer to discrete symbolic representations as independent steps in the process (Dancygier, 2012:26-27).

The construction of narrative meaning might be highly idiosyncratic insofar as "[i]t is the interaction of the linguistically motivated aspects of interpretation with cultural or historical frames that may yield a specific reader's specific reading" (Dancygier, 2012:196). The nature of human knowledge should thus be considered. Smith and Collins (2010) offer some valuable insights. The scholars observe that

[t]here is some discussion in the situated cognition literature [...] of types of cognition that are nonsituated and hence must rely more heavily on inner representational resources, such as 
thinking about things not currently present (in fictional worlds, counterfactuals, future plans, daydreams). But even these forms of cognition do not completely evade situational constraints. First, we conceptualize counterfactual worlds or future plans in major part by flexibly recombining elements of the world we have concretely experienced [...], for our representational abilities remain grounded in sensorimotor systems. Second, even when reminiscence, planning, or storytelling free our cognition from the constraints of the immediate situation, cognition is still shaped by elements of our social context: our personal self-identities (gender, occupation, nationality, etc.), the nature of our bodies, and our socially constrained life experiences and personal relationships (Smith and Collins 2010:139-140).

Narratives can be regarded as mental structures derived from situated cognition in that language comprehension activates embodied simulations that help its users mentally access the world of the narrative. Making sense of narratives involves activating mental representations that arise from embodied experience, embedded deeply in the sociocultural context of the language user, the inseparable constituents of which are time and space. This situated view of linguistic meaning permits us to link the construction of meaning to the lived experience of the participants involved in narrative discourse. It does not seem irrelevant that this approach appears to dovetail with the cultural turn in literary studies, advocating the need for the consideration of cultural contexts in literary interpretation.

\section{SELECTED ASPECTS OF NARRATIVE EVENT CONSTRUAL}

The basic unit of narration is an event insofar as most of human communication is about situations, "events that happen and states things are in" (Radden and Dirven, 2007:171). Events that recur give rise to the emergence of event schemas,

characterised by a unique configuration of thematic roles. For example, the canonical action schema is characterised by the configuration of the roles agent and theme, as in My boyfriend kissed a girl. Thematic roles are conceptual entities associated with a unique function in a situation (Radden and Dirven, 2007:298).

The same situation might be construed differently, depending on the communicative needs of interlocutors. Construal can be defined as "the speaker's choice among alternative ways of conceptualising and describing a scene; e.g. the choice between half full and half empty in describing the contents of a bottle" (Radden and Dirven, 2007:337). Attention underlies many construal operations. Entities/ relations considered important acquire greater salience in specific situational contexts. In narratives, linguistic prompts are used to guide the receiver's attention during online comprehension. Engaging in narrative discourse imposes demands on the participants. To achieve successful communication, they must converge their attention within the same frame of reference, which, in turn, requires the coordination of the participants' thought and action. 
Many cognitive studies of narratives address the issue of empathy and perspective-taking. The comprehension of narrative prose elicits the adoption of a specific perspective on the events described, which generates the construction of fictive entities (narrator, characters), as well as organises the way they are represented in the reader's mind (Rembowska-Płuciennik, 2010:73-74). Such language comprehension can activate cognitive strategies used to interact with others in real-life situations. Empathy as a cognitive phenomenon involves the language user's active engagement in the construction of the narrative, as well as its comprehension. That is, we do not restrict the application of empathy to the reader/ listener of a story. On the contrary, narrative involves the adoption of a particular perspective on the events described not only during online comprehension, but also while structuring the information to be included in the narrative form. Since we focus on the author's engagement in telling a narrative, we refer to conventional narrative devices that help establish a particular viewpoint on the described events. Empathetic narrative techniques may concern, for instance, character identification (e.g. depicted actions, quality of attributed speech), and narrative situation (including point of view and perspective) (Keen, 2006:216).

Establishing a temporal viewpoint is pivotal for tracing correspondences between events in a narrative. Tracking the order behind the sequences of events located in narrative space-time may sometimes require familiarity with narrative conventions on the part of the reader. What complicates the matter is human conceptualisation of time that might defy the application of absolute spatial and temporal coordinates of the Newtonian universe. Fludernik (2003) has underscored the intricacy of the problem, saying:

[...] the understanding of temporality becomes increasingly divorced from objective or scientific notions of time and moves towards more psychological, subjective and contextually malleable conceptions of temporality. Instead of a continuous uniform band of time stretching from one point to another, a spatial coordinate that extends into infinity, time - like post-Einsteinian space - becomes warped, discontinuous, three-dimensional. Reading time embraces not only the number of hours spent turning the pages of a book; it additionally comprises the expectations and interpretative moves of the reader, the suspense moment, the computing of alternative outcomes or developments, and the emotional consummation of narrative closure. These aspects of narrative reception straddle the merely temporal quality of the reading process in the same way that the experience of time in memory, or even in everyday perceptions of lived temporality, is entangled with the emotional impact on the individual psyche. The cognitive order of the reading process is therefore closer to the experience of time than to the notion of clock-time extending from the past into an infinite future (Fludernik, 2003:120).

We might expect that the narrative should contain some textual markers on the basis of which the reader can form some expectations as to the development of the story. The knowledge of event schemas is instrumental in the author's encoding 
of the descried events in a manner ensuring that the reader will be able to unpack the conceptual import.

How can the author signal the segmentation of events so as to facilitate the reader's comprehension of the story? As already suggested, the common ground shared by the participants of narrative discourse helps construct narrative meaning. This entails participation in a given culture, the continuity of which implies the co-existence of various time-scales one might adopt while considering different events. Community members may be reasonably expected to know the patronymic relations between different patches of time expressed by lexical items such as millennium, century, year, or this year, last month, next Tuesday (cf. Tversky and Zacks, 2013). Various grammatical devices, such as conjunctions/adverbs (e.g. before, after), and tenses, combined with markers of aspect and modality (e.g. have done, will be reading, might have been), help the reader form some predictions as to the unfolding of narrative events construed at different levels of temporal granularity, or temporal scales specific to diverse types of events. Importantly, various linguistic prompts can function as cues for opening mental spaces of diverse time-scales (cf. Radden and Dirven, 2007)1.

The issue of event sequences in narratives can be subsumed under the umbrella term of linguistic iconicity, the phenomenon of form being motivated by the meaning it conveys. Following ordo naturalis entails the unmarked sequencing of events in that, for instance, the order of events expressed in a sentence (the classic example being veni, vidi, vici) reflects their sequencing in real life. In the case of literary narratives, the less prototypical structuring of the temporal dimension of the story may be used to strengthen the reader's emotional response to the described events and thus the receiver's immersion in the fictive world of the narrative. It is the author's task to demonstrate the craft of skilful management of temporal relations. Should s/he employ less conventional means, the reader's expectations might be flouted by the author's failure to adhere to narrative conventions. This might be done to achieve a desired effect, intended by the narrative's author. In what follows, we discuss Zbigniew Herbert's selection of temporal granularity in his essay Attempt at a Description of the Greek Landscape, and the significance of the selected time-scales for the construal of events in the narrative $^{2}$. It is argued that the temporal grains imposed by the poet on the narrative

${ }^{1}$ The scope of the paper does not allow us to provide a more comprehensive account of the problem. Therefore, we do not offer detailed insights, for instance, into the metaphorical relation between the concepts of SPACE and TIME, although the fact that they constitute homologous categories should be noted (see Evans, 2007).

${ }^{2}$ The quotes from the Polish edition of Attempt... come from Herbert (2014), the quotes in English - from Herbert (2010). For the economy of space, we indicate the sources only once, in the first quotation from the Polish text and its translation. Furthermore, we can merely hint at the (un)translatability of Herbert's text. We touch on the issue by indicating that Herbert's linguistic usage can be idiosyncratic. The intricacy of the poet's linguistic expression is often veiled. The translator 
events is important because it imposes order onto the information conveyed by the narrative. This facilitates the creation of the knowledge about the past on the part of the reader. Specifically, temporal granularity is a structuring device used to share knowledge in a community insofar as the temporal grain can be conceived as an index signalling potential relations between events presented in the essay. Even though many of the events discussed in the subsequent sections are not causally connected, they are shown to intertwine and form a holistic image of Greece.

\section{ZBIGNIEW HERBERT'S ATTEMPT AT A DESCRIPTION OF THE GREEK LANDSCAPE: THE TEMPORAL GRANULARITY OF EVENTS}

Herbert is one of the Polish poets whose work has been the source for many thorough literary and linguistic investigations. The scope of the paper does not allow us to account for all of the intricacies of the way in which Herbert adjusts the granularity of temporal scales in the construal of events in his essay. Our aim is necessarily more humble in that, within the scope allowed, we can only investigate some selected aspects of how Herbert constructs the temporal granularity of events that happened on his journey to Greece.

The narrative is based on the cognitive model of journey, and thus imposes the prospective direction on events, following the ordo naturalis principle. Based on their knowledge of the journey script, the reader can make certain assumptions as to the sequence of events. The motion event schema provides the overall framework for the conceptual organisation of narrative events. We may expect that in the course of the narrative we will mentally traverse the spaces of Greece, the description of which corresponds to the time of the poet's present. We can also assume that the order of the travel from the Greek mainland to the islands corresponds to the real-life sequence of the journey. Such online comprehension invokes the SOURCE-PATH-GOAL image schema. More specifically, the opening sentence of the essay (Do Grecji jechatem na spotkanie z krajobrazem, Herbert, 2014:23; 'I went to Greece to encounter the landscape'; Herbert, 2010:440) includes the dimensional preposition $d o$ 'to', indicating the goal of the journey'.

should tackle with due caution both the informal vocabulary Herbert sometimes uses and the deceptively simple syntax of his verses (see also Jarniewicz, 2012). The rendering of the poet's essay into English is no less challenging than the translation of his poems.

${ }^{3}$ The example also illustrates the challenges of rendering temporal granularity in the English translation of the essay. Specifically, while Herbert uses the Polish imperfective form jechatem 'I was going' (an unbounded process), in the English version the reader finds I went, equivalent to the Polish perfective form of pojechatem (a bounded process). What follows is a subtle change of the temporal grain that occurs in the English translation. Whereas the essay's opening sentence in Polish prompts the reader to immerse in the poet's recollection of his travel to Greece, the use of the phrase 
The sentence that begins the next paragraph (Sądzilem, że będzie to przedlużenie krajobrazu wloskiego; 'I thought it would be a continuation of the Italian landscape') signals the opening of the mental space of expectation. The conjunction ale 'but' that starts the following clause (Ale juz rankiem ... zrozumiałem... Herbert 2010:23; 'But by morning... I understood...'; Herbert, 2010:440) acts as a creator of a mental space in which the original expectation is flouted, enticing the inference that while reading Herbert's journey to Greece, the reader should relinquish any precipitous judgements. In particular, it follows that the poet's rendering of the Greek landscape should not be construed as a mere description of the physical space ${ }^{4}$.

Indeed, from the first few lines of the third paragraph, we learn that the landscape poses a challenge to the poet's attempts (Jest to krajobraz wymykajacy sie opisowi przez sama swoja naturę; 'It is a landscape that by its very own nature defies description'). It is the fifth paragraph, beginning with the phrase geolog mówi 'the geologist says', that invokes a new frame of temporal scale. So far, the reader has been immersed in the mental space of the present. Now, the recipient of the story is suddenly placed within a new temporal space encompassing geological developments that took millennia to complete. Since they are scanned in a summary manner, the vast time-scale is compressed. The author sets the temporal reference with the employment of the proper nouns Tetyda 'Tethys' (the ancient sea), Angara 'Angara', and Gondwana 'Gondwana' (ancient land masses).

This kind of conceptual simplification facilitates the manipulation of temporal granularity in the narrative. For instance, in Dzisiejsze Morze Śródziemne jest tym, co pozostalo zdawnej Tetydy; 'The Mediterranean is what is left of ancient Tethys', Herbert uses the strategy of, what might be called, temporal "zooming in/out", whereby the time granularity is flexibly adjusted so as to mark the shifts between mental spaces evoked within one sentence: in the Polish version, the poet mentions dzisiejsze Morze Śródziemne, lit. 'today's Mediterranean', and talks about the remnants of dawnej Tetydy, lit. 'former Tethys'. Importantly, the strategy is applied not only to this one instance, but it seems to constitute an organising principle of the whole narrative, which implies a specific time conceptualisation pattern. The temporal arrangement of events described by Herbert is based on the image-schematic conceptualisation of time in which the temporal dimension is spatialised and projected onto a spatiotemporal continuum that extends not only along the horizontal and vertical axes, but also along the depth axis. Thus, the

I went encourages the reader to construe the process in terms of the actual experience of travelling, rather than as an attempt at the mental reconstruction of the experience.

${ }^{4}$ The issue of undertaking attempts to capture reality in a poetic form reappears in Hebert's oeuvre; cf. the poems Chciatbym opisać 'I would like to describe...', Próba opisu 'Attempt at a description' (Herbert, 2007). 
temporal dimension of the present is metaphorically deepened so as to embrace the past. Herbert's attempt to vivify the past of ancient Greece can be illustrated with another example, which, in accordance with the story, concerns the depiction of the localisation of the village Psychro (Wioska nazywa się Psychro. Leży u stóp jednej z najwyższych gór Krety-Dikte. [...] Nachylenie poziomów jest gwaltowne [...] waskie korytarze, zakamarki potegują wrażenie lepkiej, biologicznej tajemnicy narodzin; 'The village is called Psychro. It is situated at the foot of one of the highest mountains on Crete - Dikte. [...] The downward gradient is steep [...] narrow corridors and crannies strengthen an impression of the moist, biological mystery of birth'). The author takes the reader on a journey down the cave (Diktaion antron) where, as the legend has it, Zeus was born, but is quick to return to the present of contemporary Greece (Wyjście z groty jest wyzwoleniem od dusznych ciemności [...] Dolina życia zakuta ze wszystkich stron przez jalowe góry; 'To leave the cave is to be liberated from oppressive darkness $[\ldots]$ The valley of life is surrounded on all sides by a chain of barren mountains').

It seems that traversing the spaces of Greece constitutes an excuse for the exploration of the possibility to render personal experience, in particular, the poet's idiosyncratic perception of the Greek landscape. The closing lines of the essay bring this idea to the fore:

Zdaję sobie sprawę, że to, co napisałem, nie odpowiada tytułowi. Z tematu pejzażu pióro zbyt często ześlizgiwało się w sferę legendy i historii. [...] Pokusa opisywania i porażki opisywactwa. Nie udało mi się nawet wyrazić kształtu i koloru oliwki. A przecież znam dokładnie przynajmniej jedną tuż koło muru ogradzającego pałac Minosa w Knossos. Policzyłem wzrokiem wszystkie jej liście i noszę w sobie dokładnie jej kontur. Ale trzeba być Dürerem, żeby z tego doświadczenia zrobić przedmiot. [...] Chciałem opisać.

[I am aware that what I have written does not correspond to its title. Too often I have slid from the theme of landscape into the sphere of legend and history. [...] The lure of description and the failures of mere descriptiveness. I haven't even managed to articulate the shape and colour of an olive tree. Isn't there at least one I know in precise detail, right by the wall enclosing the palace of Minos in Knossos? I have counted each of its leaves with my eyes and I carry its exact contour within me. But you would have to be Dürer to make an object from this experience. [...] I wanted to describe it.].

Herbert's attempt at a description of the Greek landscape is, in fact, an attempt at the reification of the experience of physically moving through space, but mentally travelling in time. The problem the poet seems to be acutely aware of is the inherent changeability of life. The discrete chunking of the spatiotemporal experience could only lead to the dissection of the lived events of which the journey consisted into separate components. Herbert's intention, however, seems to concern the unification of the many events into one coherent whole. What, then, does Herbert do 
to achieve the effect of capturing the gestalt of his Greek experience, the sensation of the co-existence of the past and the present?

The general knowledge of the origins of European culture is common to the author and target Polish readers. Yet, the poet intertwines a great deal of academic information into the fabric of the narrative. In the early decades of the second half of the $20^{\text {th }}$ century, much of the information was unattainable to the general Polish readership. The need for empathy on the author's part stems from the fact that, when writing the essay, Herbert had to consider the kind of information the general Polish readership under the communist regime might not be familiar with. This was necessary not only due to the readers' lack of access to specific academic references, but also because of their inability to travel abroad freely. Despite these historical constraints, the detailed scholarly knowledge is used to the narrator's advantage, as he evokes many detailed facts from the concrete, embodied experience of living in ancient Greece. Thus, many predicates pertain to habitual actions. For instance, in the section on Epidaurus, Herbert discusses the practices undertaken by the ill who frequented the place devoted to Asclepius (e.g. Rytual, jakiemu poddani byli chorzy oczekujacy pomocy boga, byt prosty; 'The ritual to which the sick awaiting the god's help were subjected was straightforward'). Within the framework of habitual actions undertaken on a regular basis, the reader can find specific instance of events construed as specific points in time. We thus read about the story of Klintas of Thebes, who "had a vast number of fleas on his whole body", but "left the incubatorium cured" (Herbert, 2010:443), mentioned in the context of the poet's report about the relationship between Greek medicine and the religious beliefs of ancient inhabitants of Greece. The Epidaurus section also informs us about Herbert's technique of varying the temporal grain within individual episodes, the level of specificity being established by the use of relevant temporal expressions (Liczba chorych przebywających jednocześnie w Epidaurze dochodzita do ośmiuset. Dopiero w III wieku przed Chr. powiększono portyk; 'The number of [the] sick who visited Epidaurus at any given time could reach eight hundred. Not until the third century B.C. was the portico [...] enlarged'). By reconstructing the past events contained within particular physical spaces, the poet enables the reader to mentally enter the world of the narrative, in which the past intermingles with the present. Due to the spatial and temporal qualities of simulation experience occurring in online comprehension, the reader can become immersed in the narrative's world to the extent of being "there conceptually" (Barsalou, 2016). Indeed, Herbert has the reader shift between the many temporal viewpoints on the described events, which leads to establishing a multi-stable perception of the time dimension. For instance, in the opening lines of the Mycenae episode, we find a direct reference to an ancient text (Oto Mykeny bogate w zloto i skrwawiony palac Pelopidów; 'Here is Mycenae rich 
in gold and the blood-stained palace of the Pelopides'5), immediately followed by reference to the contemporary Greek museum, housing the old treasures (Resztki zlota znajduja się teraz $\boldsymbol{w}$ ateńskim muzeum; 'The remains of the gold are now in the museum of Athens'). The implied, movable temporal viewpoint pulls down boundaries between the present and the past, both of which are experienced by the reader in a situated manner, by mentally immersing the receiver in the experience of the Greek memoryscape ${ }^{6}$. The individual events-episodes of the journey seem separated from one another due to the use of spatial expressions indicating their physical locations. However, their time granularity is such that it does not allow delineating clear-cut temporal boundaries of individual episodes, because the events from the distant past are construed in such a way that the reader constructs them as coexisting with those of the present.

Herbert's use of the dynamically shifting viewpoints obliterates spatial-temporal divisions of the world's history into separate eras or historical periods, the contours of which are conventionally distinguished in an arbitrary fashion. Since the narrative events are not ordered in a chronological sequence, the world's history as presented in the narrative forms a panchronic gestalt ${ }^{7}$. The physical locations depicted in the essay are shown as offering support for human memory, and giving mental access to the conceptual realm of panchrony embracing the whole of human history. Conceptually, panchrony subsumes other mental spaces related to specific events of the narrative, each of which with its own temporal grain.

\section{CONCLUSIONS}

Our analysis has shown that the construal of the temporal granularity of the described events is not irrelevant for the comprehension of the narrative. Herbert's account of his journey to Greece might be seen as an instance of intersemiotic translation insofar as his essay constitutes a literary rendering of lived, multimodal experience (e.g. Przy samej ziemi macierzanka, tymianek, mięta -

${ }^{5}$ In the notes to Attempt... in Herbert (2010), we can find the information that the line pertains to Homer's Iliad, Book VII. 180; XI. 46 (Herbert, 2010:699).

${ }^{6}$ The construal of temporal granularity in the first two lines of the section on Mycenae is intricate. The poet evokes the mental space of what at first may pertain to a present situation (the Polish item oto 'here is'), but the reader must contextualise the scene relative to the presence of the quotation marks, and the subsequent phrase skrwawiony pałac Pelopidów 'the blood-stained palace of the Pelopides', which invokes the framework of both the history of ancient Greece, its literature and mythology. In the following sentence, as the poet resumes the viewpoint anchored in the times of modern Greece, he has the reader mentally confront the Mycenae past glory with the present modest location of the treasure by juxtaposing the imagery of the Mycenae former wealth with the notion of its meagre vestiges in the Athenian museum.

${ }^{7}$ Our approach to the idea of panchrony has been developed and discussed, for instance, in Stadnik $(2015,2016)$. 
aromaty upalu; 'Low against the earth, thyme and mint - the aromas of heat' ${ }^{8}$ ). From this perspective, the poet emerges as an intercultural mediator within the sphere of Western European culture. On Herbert's account, Poland under the communist regime is counted as part of the Western tradition that derives from the common European heritage of ancient Greece (Sztuke grecka można poznać nieźle w muzeach europejskich; 'One can make a perfectly good study of Greek art in European museums'). However, since Poles could not travel abroad freely at that time, the political separation of the Polish nation from Western Europe was tantamount to physical isolation as well. In a sense, the country's borders delimited the freedom of physical movement for the majority of regular Polish citizens. It thus seems reasonable to argue that, in his essay, the poet acts also as an intercultural mediator shaping the narrative into a guide to Greece presented as not only a physical space, but also as the centre of the axiological universe from which Poland's culture also derives. It is because of the poet's role as an inter- and intra-cultural mediator that Herbert's narrative is necessarily an erudite essay. As the poet shares his knowledge with the Polish reader, he manipulates the temporal granularity of events described in the essay by evoking in the reader's mind different time-scales. In this way, the poet contextualises various information chunks relative to the history of specific localities, which helps the reader interconnect the various mental spaces related to different events that occurred within the particular spaces?.

The analysis has also shown the significance of considering the situated, often idiosyncratic, nature of human knowledge for the construction of story worlds. It may be concluded that it is the individual's knowledge, based on their lived experience, that emerges as the primary, albeit tacit, subject of the story (cf. Herbert, 1999). As we learn from Herbert's personal notes he made while in Greece, the poet had prepared detailed sketches of his experiences in Greece. As such, the materials may give us some insight into the process of constructing the essay. Importantly, in the poet's Greek diary we encounter a time granularity of events that bears a close resemblance to the construal of episodes depicted in Herbert's narrative about the Greek landscape.

\footnotetext{
${ }^{8}$ The Polish macierzanka, tymianek are both rendered as thyme.

${ }^{9}$ For instancje, Bandy Achajów [...] zaczęty przenikać do Grecji od 2000 r. przed Chr. Szybko opanowali Pólwysep Peloponeski. Wilcze apetyty zaprowadzity ich dalej na poludnie [...] Achajowie przedsiębrali wyprawy tupieżcze [...] Wracali z bydlem, złotem i niewolnikami; 'Bands of Achaians [...] began to reach Greece from 2000 B.C. They quickly conquered the Peloponnesian peninsula. Their wolfish appetites drove them farther south [...] The Achaians undertook looting expeditions [...] They returned with livestock, gold, and slaves'. This passage is followed by a sudden temporal shift to the present (Kiedy się zmierzcha, najlepiej usiaśś przy drodze prowadzacej do groby Agamemnona [...] i raz jeszcze rzucić okiem na cyklopowe mury $i$ spiętrzone ruiny Myken; 'When dusk falls, it's best to sit by the road leading to Agamemnon's grave $[\ldots]$ and cast another eye on the Cyclopean walls and the piled-up ruins of Mycenae').
} 
Herbert captures the historical continuity of Greece, offering glimpses into how its cultural heritage is deeply entrenched in the physical spaces of the land. The poet constructs temporal bridges across different time-scales. While his tool is language, it must be indicated that the spatial organisation of the text itself is of pivotal importance during online comprehension. Although various linguistic devices are used to signal the beginning of a new episode by establishing a mental space relevant for a given event, the graphic organisation of the text contributes to the reader's mental construction of the narrative's world. Importantly, the many temporal mental spaces are intertwined in that they share the same initial reference orientation anchored in the space of contemporary Greece. The overall effect is that of establishing a panchronic reading of the text, in which the reader is mentally projected to the different moments embraced within a given space, as Greek landscape comes to be construed as a memoryscape.

\section{BIBLIOGRAPHY}

Barsalou, Lawrence. (2016). Situated Conceptualization: Theory and Applications. In: Yann Coello, Martin H. Fischer (eds.). Foundations of Embodied Cognition. East Sussex, UK: Psychology Press.

Dancygier, Barbara. (2012). The Language of Stories: A Cognitive Approach. Cambridge: Cambridge University Press.

Evans, Vyryan. (2007). A Glossary of Cognitive Linguistics. Edinburgh: Edinburgh University Press.

Fludernik, Monika. (2003). Chronology, Time, Tense and Experientiality in Narrative. Language and Literature, vol. 12 (2) (05/2003), pp. 117-134.

Herbert, Zbigniew. (1999). Diariusz grecki. Zeszyty Literackie, 68. Zeszyty Literackie: WarszawaParyż-Mediolan, pp. 42-62.

Herbert, Zbigniew. (2007). Collected Poems 1956-1998. Translated by Alissa Valles. London: Atlantic Books.

Herbert, Zbigniew. (2010). The Collected Prose 1948-1998. Translated by Alissa Valles. New York: Harper Collins.

Herbert, Zbigniew. (2014). Barbarzyńca w podróży. Warszawa: Zeszyty Literackie.

Horton, William. (2012). Shared Knowledge, Mutual Understanding and Meaning Negotiation. In: Hans-Jorg Schmid (eds.). Cognitive Pragmatics (pp. 375-404). Berlin: De Gruyter Mouton.

Jarniewicz, Jerzy. (2012). Gościnność słowa. Szkice o przekładzie literackim. Kraków: Znak.

Keen, Suzanne. (2006). A Theory of Narrative Empathy. Narrative, vol. 14, no. 3, pp. 207-236.

Radden, Günter, Dirven, René. (2007). Cognitive English Grammar. Amsterdam: John Benjamins.

Rembowska-Płuciennik, Magdalena. (2010). Narracyjne modele intersubiektywności. Teksty Drugie, 2010 (4), p. 73-87.

Sharifian, Fanad. (2016). Lingwistyka kulturowa. Etnolingwistyka, 28, pp. 31-57. DOI: 10.17951/ et.2016.28.31.

Smith, Eliot, Collins, Elizabeth. (2010). Situated Cognition. In: Batja Mesquita, Lisa Feldman Barrett, Eliot Smith (eds.). The Mind in Context (pp. 126-145). New York: Guilford Press.

Stadnik, Katarzyna. (2015). Chaucer's Choices. Through the Looking-Glass of Medieval Imagery. Lodz Studies in Language: Vol. 38. Frankfurt am Main, Berlin, Bern, Brussels, New York, Oxford, Vienna: Peter Lang. 
Stadnik, Katarzyna. (2016). Entering the World of the Sacred: Memory, Time and Space in John Paul II's "Roman Triptych". Horyzonty Wychowania, 36, pp. 67-86, DOI: 10.17399/HW. 2016.153604.

Tversky, Barbara, Zacks, Joffrey, Hard, Bridgette (2007). The Structure of Experience. In: Thomas Shipley, Jeffrey Zacks (eds.). Understanding Events (pp. 436-464). Oxford: Oxford University. Tversky, Barbara, Zacks, Jeffrey. (2013). Granularity in Taxonomy, Time, and Space. Motion Encoding in Language and Space. DOI: 10.1093/acprof:oso/9780199661213.003.0007.

\section{STRESZCZENIE}

Narracje stanowią nieodłączną część ludzkiego życia; pełnią ważną funkcję współtworzenia indywidualnej i zbiorowej tożsamości, pozwalając na dzielenie się wiedzą zgromadzoną przez wspólnotę. Narracje mogą być przekazywane za pomocą wielu różnych, często mieszanych mediów. Niezależnie od zastosowanego środka przekazu pomagają tworzyć przestrzeń intersubiektywnie podzielanej wiedzy, wartości i przekonań wspólnoty. W przypadku narracji językowych konstruowanie znaczenia wymaga od czytelnika wykazania się zdolnością do empatii, rozumianej jako umiejętność przyjęcia punktu widzenia innego niż nasz własny. W tym sensie, dzięki narracjom, możemy nauczyć się przyjmowania perspektywy innego uczestnika wspólnoty. W artykule koncentrujemy się na sposobach organizacji narracji literackiej pod względem struktury czasoprzestrzennej przedstawianych zdarzeń. W szczególności interesuje nas sposób, w jaki Zbigniew Herbert konstruuje narrację w swoim eseju podróżniczym Próba opisania krajobrazu greckiego, gdzie warta uwagi jest czasoprzestrzenna segmentacja (wyodrębnianie) opisywanych zdarzeń.

Slowa klucze: czas, narracja, panchronia, zdarzenie, Zbigniew Herbert

\section{SUMMARY}

Narratives are integral to human lives. As a means of communication, they contribute to the formation of individual and collective identity: not only do narratives enable imparting information, but also help establish and maintain social bonds between community members. Regardless of the specific medium used, narratives help humans establish and maintain the realm of intersubjectivity by allowing to renounce the ego-centric, individual perspective and adopt the viewpoint from which the other comprehends the world. Thus, narratives facilitate the emergence of a shared framework of reference, promoting intersubjective temporal and spatial orientation. The paper address the issue of time conceptualisation in narratives. Specifically, the analysis presented in the paper uncovers specific time conceptualisation patters underlying the construction of narrative events in Zbigniew Herbert's Attempt at a Description of the Greek Landscape.

Keywords: event, narrative, panchrony, time, Zbigniew Herbert 